\title{
ANALISIS KEINTEGRASIAN MUATAN PELAJARAN SEKOLAH DASAR KELAS I TEMA LINGKUNGAN BERSIH, SEHAT, DAN ASRI DALAM IMPLEMENTASI KURIKULUM 2013
}

\author{
L.P. Ratna Dewi ${ }^{1}$, A.A.I.N. Marhaeni ${ }^{2}$, N. Dantes ${ }^{3}$ \\ ${ }^{123}$ Program Studi Pendidikan Dasar \\ Universitas Pendidikan Ganesha \\ Singaraja, Indonesia
}

e-mail: ratnadewi.3@gmail.com¹, ngr.marhaeni@undiksha.ac.id ${ }^{2}, \underline{\text { dantes@undiksha.ac.id }}{ }^{3}$

\begin{abstract}
Abstrak
Penelitian ini bertujuan untuk mengetahui dan mendeskripsikan keintegrasian pada materi pembelajaran, rancangan langkah-langkah kegiatan pembelajaran, rancangan penilaian, rancangan media dan sumber belajar Sekolah Dasar kelas I tema Lingkungan Bersih, Sehat dan Asri. Penelitian ini menggunakan deskriptif kualitatif. Teknik pengumpulan data yang digunakan adalah metode dokumentasi. Analisis data yang digunakan yaitu pengumpulan data, reduksi data, penyajian data, dan penarikan kesimpulan. Berdasarkan analisis data, diperoleh hasil penelitian bahwa: 1) terdapat keintegrasian pada materi pembelajaran dengan tingkat keintegrasian sangat baik sebesar $94.8 \%$ dengan klasifikasi multidisipliner. 2) terdapat keintegrasian pada rancangan langkah-langkah kegiatan pembelajaran dengan tingkat keintegrasian baik sebesar 83,5\% dengan klasifikasi intradisipliner, 3) terdapat keintegrasian pada rancangan penilaian dengan tingkat keintegrasian sangat baik sebesar $95,8 \%$ dengan klasifikasi intradisipliner, 4) terdapat keintegrasian pada rancangan media dan sumber belajar dengan tingkat keintegrasian sangat baik sebesar 89,7\% dengan klasifikasi intradisipliner. Ini berarti, analisis keintegrasian pada keempat komponen sudah baik dan dapat diimplementasikan di Sekolah Dasar.
\end{abstract}

Kata Kunci: Keintegrasian, Kurikulum 2013

Abstract

This study aims to determine and describe the integration of learning materials, the design of the steps of learning activities, the design of assessment, the design of media and learning resources for elementary school grade I with themes of Clean, Healthy and Beautiful Environment. This research uses descriptive qualitative. The data collection technique used is the documentation method. There were four steps in analyzing the data namely collection, data reduction, data presentation, and conclusion. Based on data analysis, the results of the study showed that: 1) there is integration in learning material with excellent integration level of $94.8 \%$ with multidisciplinary classification. 2) there is integration in the design of the steps of learning activities with a good integration rate of $83.5 \%$ with intradisciplinary classification, 3) there is integration in the assessment design with a very good integration level of $95.8 \%$ with intradisciplinary classification, 4) there is integration in media design and learning resources with excellent integration level of $89.7 \%$ with intradisciplinary classification. This means that the integration analysis in the four components is good and can be implemented in elementary schools.

Keywords: integration, curriculum 2013

\section{PENDAHULUAN}

Kurikulum seperti kompas dalam memandu kapal untuk berlayar dalam dunia pendidikan. Kurikulum memainkan peran penting dalam pengorganisasian, mengarahkan, dan membimbing kegiatan pembelajaran. Hubball \& Burt (Rumahlatu, dkk. 2016) menyatakan bahwa reformasi 
kurikulum adalah suatu yang kompleks, beragam, dan proses berulang, di mana ide-ide di buat menjadi kebijakan, di ubah menjadi perilaku, dan di ekspresikan sebagai tindakan sosial. Terkait dengan pentingnya kurikulum dan reformasi, pemerintah di Indonesia terus berupaya untuk meningkatkan kualitas pendidikan, salah satunya yaitu Kurikulum 2013.

Kehadiran kurikulum 2013 diharapkan akan membawa perubahan dalam menyikapi kesenjangan yang telah terjadi di dunia pendidikan. Disamping itu, kurikulum 2013 juga diharapkan dapat menghasilkan insan Indonesia yang produktif, afektif, inovatif, dan kreatif melalui penguatan aspek sikap, keterampilan dan pengetahuan yang terintegrasi, dimana ketiga aspek penting ini yang menjadi fokus dalam kegiatan pembelajaran.

Pemerintah menyediakan buku guru dan buku siswa dalam mengimplementasikan Kurikulum 2013. Buku guru merupakan pedoman pembelajaran pengintegrasian materi ajar, teknik penilaian, serta panduan dalam melaksanakan pembelajaran di kelas yang didesain menggunakan pendekatan ilmiah dan asesmen otentik. Sedangkan buku siswa berisi kegiatan pembelajaran yang harus dilalui peserta didik untuk mencapai kompetensi yang diharapkan dalam pembelajaran Kurikulum 2013. Buku teks berperan penting dalam pelaksanaan kegiatan dan penilaian pembelajaran di kelas yang sesuai dengan tuntutan Kurikulum 2013. Buku teks yang diterbitkan oleh pemerintah diharapkan dapat mewujudkan tujuan pembelajaran.

$$
\text { Kurikulum } 2013 \text { yang }
$$

dikembangkan dalam bentuk kompetensi inti (KI) dan kompetensi dasar (KD). Kompetensi inti dalam Kurikulum 2013 terdiri atas empat dimensi yang saling terkait yaitu sikap spiritual/KI-1, sikap sosial/KI-2, pengetahuan/KI-3, dan keterampilan/KI-4. Pada Sekolah Dasar keempat kompetensi tersebut pembelajarannya yakni dengan menggunakan pendekatan tematik terpadu (integrasi).

$$
\text { Menurut Prastowo (2019:1) }
$$

pembelajaran tematik adalah salah satu model pembelajaran terpadu (integrated learning) pada jenjang taman kanak-kanak atau sekolah dasar untuk kelas awal yang didasarkan pada tema-tema tertentu yang kontekstual dengan dunia anak. Integrasi dalam pembelajaran diharapkan memberikan pemahaman yang komprehensif pada diri peserta didik dan lingkungannya. Hal ini terkait dengan pemahaman bahwa diri manusia adalah bagian dunia lebih luas, sehingga peserta didik mampu memahami pengetahuan yang diterimanya melalui kurikulum beserta implementasi dan perkembangannya dalam kehidupan sehari-hari.

Pembelajaran tematik terpadu berpusat pada siswa (student centered learning), yaitu dengan melibatkan peserta didik dalam proses belajar atau mengarahkan peserta didik secara aktif terlibat dalam proses pembelajaran. Selain itu, pembelajaran tematik terpadu juga memberikan kesempatan kepada peserta didik untuk menghubungkan pengalaman dan pengetahuan yang dimiliki sehingga peserta didik lebih mudah menyelesaikan masalah dan memenuhi kebutuhan mereka akan pengetahuan (Huber \& Hutchings, 2008). Selain itu, Randle (2010: 85) menambahkan bahwa pembelajaran tematik terpadu menekankan pada pengintegrasian semua disiplin ilmu dengan pengalaman belajar yang berbasis pada pengalaman peserta didik dan struktur dunia nyata, sehingga mendorong pembelajaran menjadi lebih bermakna.

Dengan adanya keterpaduan tema dalam pembelajaran maka ada beberapa manfaat yang dapat dirasakan nantinya sebagai berikut: 1) siswa mampu melihat hubungan-hubungan yang bermakna sebab isi/materi pembelajaran lebih berperan sebagai sarana atau alat bukan tujuan akhir; 2) dengan adanya pemaduan mata pelajaran maka penguasaan konsep akan semakin baik dan meningkat; 3) siswa mendapat pengertian mengenai proses dan materi yang terpecah-pecah; 4) tumpang tindih materi dapat dikurangi karena menggabungkan beberapa kompetensi dasar dan indikator serta isi mata pelajaran. 
Meskipun pembelajaran tematik
sudah dikonsepkan dan dirancang
sedemikian rupa, namun realitanya
kebijakan tersebut tidak bisa terwujud
dengan baik. Guru Sekolah Dasar dikelas
rendah tetap saja menggunakan cara
pembelajaran konvensional yaitu berbasis
mata pelajaran. Guru yang menulis pada
RPP menggunakan pembelajaran tematik yang memadukan beberapa mata pelajaran dalam satu tema, namun praktiknya sangat jauh dari apa yang menjadi ciri khas pembelajaran tematik itu sendiri. Selain itu, penguasaan materi pembelajaran tematik oleh guru kelas rendah kurang maksimal. Hal ini disebabkan oleh kurangnya pemahaman tentang pembelajaran tematik tersebut. Guru merasa kesulitan dalam melaksanakan pembelajaran tematik, akibatnya pembelajaran tidak dapat berjalan secara efektif. Sejalan dengan penelitian Suryati (2010) menyatakan bahwa ada beberapa alasan guru tidak siap dalam melaksanakan pembelajaran tematik. Pertama, ada penolakan melakukan itu karena bagi guru persiapan yang dituntut terlalu banyak. Kedua, rapor harus mencantumkan nilai setiap mata pelajaran. Ketiga, guru belum memiliki kompetensi yang cukup dalam mengimplementasikan pendekatan tersebut.

Berdasarkan pengamatan peneliti, pembelajaran yang terjadi selama ini di Sekolah Dasar khususnya di kelas rendah adalah guru kurang kritis dalam menganalisis buku guru dan buku siswa yang digunakan saat mengajar. Sebelum menggunakan buku guru dan buku siswa dalam proses belajar mengajar di kelas, guru sebaiknya melakukan analisis buku terlebih dahulu, sehingga jika ditemukan adanya kekeliruan atau ketidaktepatan di dalam buku tersebut, maka guru dapat mengatasinya dengan melakukan langkah-langkah tindak lanjut yang diperlukan.

Sementara itu, berdasarkan penelitian yang dilakukan oleh Anwar dan Ali (2015) ditemukan bahwa pada buku teks kurikulum 2013 berupa buku guru dan buku siswa secara keseluruhan menunjukkan kesesuaian. Namun, sejauh ini belum ada kajian secara langsung yang membahas tentang keintegrasian muatan pelajaran di buku guru dan buku siswa terutama dalam komponen materi pembelajaran, kegiatan pembelajaran, penilaian, media dan sumber belajar. Maka, peneliti melakukan kajian lebih dalam mengenai keintegrasian materi pembelajaran (MP), rancangan langkahlangkah kegiatan pembelajaran (RLLKP), rancangan penilaian (RP) dan rancangan media dan sumber belajar (RMSB) yang terdapat di buku guru dan buku siswa Sekolah Dasar kelas I tema "Lingkungan Bersih, Sehat, dan Asri".

\section{METODE}

Pendekatan dalam penelitian ini adalah pendekatan kualitatif. Pendekatan kualitatif merupakan penelitian yang menghasilkan penemuan-penemuan yang tidak dapat dicapai (diperoleh) dengan menggunakan prosedur statistik dan caracara lain. Penelitian kualitatif memerlukan data berupa kata-kata tertulis dan data lisan yang perlu diamati lebih lanjut. Rancangan penelitian yang digunakan dalam penelitian ini adalah metode deskriptif. Alasan peneliti menggunakan metode deskriptif adalah untuk memberikan gambaran atau uraian atas suatu keadaan sejelas mungkin tanpa ada perlakuan terhadap objek yang diteliti. Tujuan dari penelitian deskriptif ini adalah untuk membuat deskripsi, gambaran atau lukisan secara sistematis, faktual dan akurat mengenai fakta-fakta, sifat-sifat hubungan antar fenomena yang diselidiki.

Dalam penelitian ini pengumpulan data dilakukan dengan dokumentasi yaitu data dikumpulkan dalam bentuk dokumen kemudian dianalisis berdasarkan empat komponen diantaranya 1) materi pembelajaran (MP), 2) rancangan langkah-langkah kegiatan pembelajaran (RLLKP), 3) rancangan penilaian (RP), 4) rancangan media dan sumber belajar (RMSB). Selanjutnya hasil penelitian di sajikan secara deskriptif. Buku acuan utama yang digunakan adalah buku guru kelas I SD/MI tematik terpadu kurikulum 2013 tema Lingkungan Bersih, Sehat dan Asri dan buku siswa kelas I SD/MI tematik terpadu kurikulum 2013 tema Lingkungan 
Bersih, Sehat dan Asri. Buku yang digunakan merupakan terbitan dari Kementerian Pendidikan dan Kebudayaan Republik Indonesia revisi 2017.

Objek penelitian ini adalah Kurikulum 2013 yang ditinjau melalui buku guru dan buku siswa di kelas I tema Lingkungan Bersih, Sehat dan Asri.

Subjek penelitian merupakan sumber informasi yang digali untuk mengungkap fakta-fakta di lapangan. Informan utama dalam penelitian yang dijadikan subyek penelitian ini adalah buku guru dan buku siswa kelas 1 tema Lingkungan Bersih, Sehat dan Asri.

Keintegrasian Kurikulum 2013

Sekolah Dasar adalah keterkaitan antara muatan pelajaran pada 4 komponen pembelajaran yaitu keintegrasian materi pembelajaran (MP), keintegrasian rancangan langkah-langkah kegiatan pembelajaran (RLLKP), keintegrasian rancangan penilaian (RP) dan keintegrasian rancangan media dan sumber belajar (RMSB) di buku guru dan buku siswa berdasarkan tujuan pembelajaran.

Keintegrasian 4 komponen pembelajaran yang dimaksud dapat diklasifikasikan menjadi 4 yaitu:

1) Integrasi intradisipliner yaitu keterkaitan antara aspek pengetahuan, keterampilan dan sikap dalam satu muatan pelajaran pada lebih dari satu tujuan pembelajaran dalam satu muatan pelajaran.

2) Integrasi multidisipliner merupakan keterkaitan antara aspek pengetahuan, keterampilan dan sikap yang menghubungkan berbagai tujuan pembelajaran dari berbagai muatan pelajaran.

3) Integrasi interdisipliner merupakan keterkaitan yang dilakukan dengan menggabungkan kompetensi dasar dari berbagai muatan pelajaran menjadi satu.

4) Integrasi transdisipliner merupakan keterkaitan berbagai muatan pelajaran dengan permasalahan yang dijumpai di sekitar.

Data yang akan dianalisis sebelumnya dikumpulkan (data collection), data yang dikumpulkan merupakan data yang berasal dari analisis keintegrasian muatan pelajaran Sekolah Dasar pada buku guru dan siswa kelas I tema Lingkungan Bersih, Sehat dan Asri. Kegiatan analisis data kualitatif menurut Miles dan Huberman (dalam Sugiyono, 2013: 337-345), terdapat empat macam, yakni:

1. Pengumpulan Data

Pengumpulan data merupakan tahap pertama yang dilakukan untuk memperoleh data yang dibutuhkan dalam penelitian. Peneliti mengumpulkan sesuai dengan pedoman penelitian yang telah disusun. Pengumpulan data dalam penelitian ini menggunakan inventori dalam bentuk matriks. Data tersebut tentang muatan pelajaran Sekolah Dasar pada buku guru dan siswa kelas I tema Lingkungan Bersih, Sehat dan Asri Kurikulum 2013 yang diperoleh peneliti melalui dokumentasi dicatat dan dikumpulkan oleh peneliti guna mendukung tahap penelitian selanjutnya.

2. Reduksi Data

Reduksi data dalam penelitian ini terdiri atas beberapa langkah, yaitu (1) menajamkan analisis; (2) menggolongkan atau pengkategorisasian; mengarahkan; (4) membuang yang tidak perlu dan (5) mengorganisasikan data sehingga simpulan-simpulan finalnya dapat ditarik dan diverifikasi. Data yang dikumpulkan dipilih dan dipilah berdasarkan rumusan masalahnya, kemudian dilakukan seleksi untuk dapat mendeskripsikan rumusan masalah. Reduksi data dapat dihitung menggunakan rumus sebagai berikut:

Keterangan:

$$
P=\frac{\sum X_{i}}{\text { Total }} \%
$$

$P$ : Presentasi Keintegrasian

$X_{i}$ : Nilai Komponen

Selanjutnya,

presentasi keintegrasian tersebut dibandingkan dengan kriteria seperti terlihat pada Tabel 1. 
Tabel 1. Konversi Penilaian Acuan Patokan (PAP) Skala Lima tentang Keintegrasian Muatan Pelajaran

\begin{tabular}{cc}
\hline Presentase Pencapaian (\%) & Validitas \\
\hline $90-100$ & Sangat Baik \\
$80-89$ & Baik \\
$65-79$ & Sedang \\
$40-64$ & Rendah \\
$00-39$ & Sangat Rendah \\
\hline
\end{tabular}

\section{Penyajian Data}

Setelah penggolongan data, maka langkah selanjutnya adalah menyajikan data. Pada penelitian kualitatif penyajian data bisa dilakukan dalam bentuk uraian singkat, bagan, hubungan antar kategori, flowchart, dan sejenisnya. Data yang disajikan dalam penelitian ini berbentuk rangkuman secara deskriptif dan sistematis dari hasil yang diperoleh, sehingga tema sentral dapat diketahui dengan mudah, dan setiap rangkuman diberikan penjelasan dengan memperhatikan kesesuaian dengan fokus penelitian. Akan tetapi, dalam penyajian data dalam penelitian ini juga menggunakan tabel untuk memudahkan dalam pengkategorian. Diharapkan dari data yang diperoleh akan memudahkan dan menjelaskan apa yang terjadi.

4. Menarik Kesimpulan/ Verifikasi

Langkah yang terakhir adalah verifikasi data untuk menarik kesimpulan. Kesimpulan dalam penelitian kualitatif dapat menjawab rumusan masalah yang dirumuskan sejak awal, tetapi mungkin juga tidak karena masalah dan rumusan masalah dalam penelitian kualitatif masih bersifat sementara dan berkembang saat penelitian berada di lapangan.

\section{HASIL DAN PEMBAHASAN}

Tabel 2. Rekapitulasi Hasil Analisis Keintegrasian Muatan Pelajaran Pada 4 Komponen Pembelajaran Klasifikasi Keintegrasian

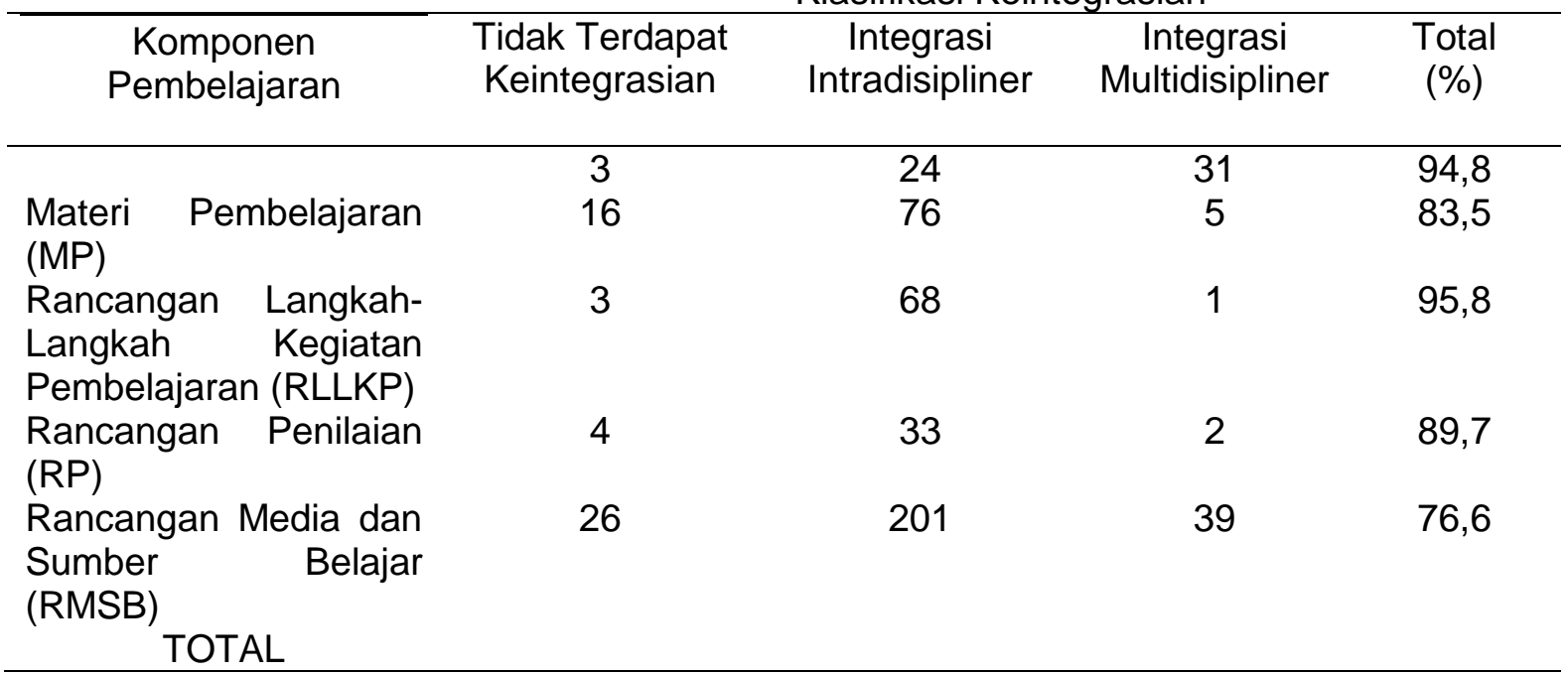

Berdasarkan pemaparan hasil analisis keintegrasian materi pembelajaran (MP) di atas dapat disimpulkan kecenderungan keintegrasian berada pada integrasi multidisipliner dengan total
31 keintegrasian. Jika dipresentasekan menggunakan rumus sebagai berikut:

$$
\begin{aligned}
& \mathrm{P}=\frac{\sum x i}{\text { Total }} \times 100 \% \\
& \mathrm{P}=\frac{55}{58} \times 100 \% \\
& \mathrm{P}=94,8 \% \text { (Sangat Baik) }
\end{aligned}
$$


Berdasarkan pemaparan hasil analisis keintegrasian rancangan langkahlangkah kegiatan pembelajaran (RLLKP) di atas dapat disimpulkan kecenderungan keintegrasian berada pada integrasi intradisipliner dengan total 76 keintegrasian. Jika dipresentasekan menggunakan rumus sebagai berikut:

$$
\begin{aligned}
& \mathrm{P}=\frac{\sum x i}{\text { Total }} \times 100 \% \\
& \mathrm{P}=\frac{81}{97} \times 100 \% \\
& \mathrm{P}=83,5 \% \text { (Baik) }
\end{aligned}
$$

Berdasarkan pemaparan hasil analisis keintegrasian rancangan penilaian (RP) di atas dapat disimpulkan kecenderungan keintegrasian berada pada integrasi intradisipliner dengan total 68 keintegrasian. Jika dipresentasekan menggunakan rumus sebagai berikut:

$$
\begin{aligned}
& \mathrm{P}=\frac{\sum x i}{\text { Total }} \times 100 \% \\
& \mathrm{P}=\frac{69}{72} \times 100 \% \\
& \mathrm{P}=95,8 \% \text { (Sangat Baik) }
\end{aligned}
$$

Berdasarkan pemaparan hasil analisis keintegrasian rancangan media dan sumber belajar (RMSB) di atas dapat disimpulkan kecenderungan keintegrasian berada pada integrasi intradisipliner dengan total 33 keintegrasian. Jika dipresentasekan menggunakan rumus sebagai berikut:

$$
\begin{aligned}
& \mathrm{P}=\frac{\sum x i}{\text { Total }} \times 100 \% \\
& \mathrm{P}=\frac{35}{39} \times 100 \%
\end{aligned}
$$$$
\mathrm{P}=89,7 \% \text { (Sangat Baik) }
$$

Berdasarkan Tabel 4.5 rekapitulasi hasil analisis keintegrasian muatan pelajaran pada 4 komponen pembalajaran di atas dapat disimpulkan bahwa terdapat keintegrasian yang ditemukan pada materi pembelajaran (RP), rancangan langkahlangkah kegiatan pembelajaran (RLLKP), rancangan penilaian (RP), rancangan media dan sumber belajar (RMSB). Klasifikasi keintegrasian pada 4 komponen pembelajaran yaitu pertama, komponen materi pembelajaran (MP) ditemukan 3 yang tidak terdapat keintegrasian, 24 keintegrasian secara intradisipliner dan 31 keintegrasian secara multidisipliner, sehingga dapat disimpulkan kecenderungan keintegrasian pada komponen materi pembelajaran (MP) yaitu integrasi multidisipliner. Kedua, komponen rancangan langkah-langkah kegiatan pembelajaran (RLLKP) ditemukan 16 yang tidak terdapat keintegrasian, 76 keintegrasian secara intradisipliner dan 5 keintegrasian secara multidisipliner. Sehingga dapat disimpulkan kecenderungan keintegrasian pada komponen rancangan langkah-langkah kegiatan pembelajaran (RLLKP) yaitu integrasi intradisipliner. Ketiga, komponen rancangan penilaian (RP) ditemukan 3 yang tidak terdapat keintegrasian, 68 keintegrasian secara intradisipliner dan 1 keintegrasian secara multidisipliner, sehingga dapat disimpulkan kecenderungan keintegrasian pada komponen rancangan penilaian (RP) yaitu integrasi intradisipliner. Keempat, komponen rancangan media dan sumber belajar (RMSB) ditemukan 4 yang tidak terdapat keintegrasian, 33 keintegrasian secara intradisipliner dan ditemukan 2 keintegrasian secara multidisipliner, sehingga dapat disimpulkan kecenderungan keintegrasian pada komponen rancangan media dan sumber belajar (RMSB) yaitu integrasi intradisipliner.

Berdasarkan pemaparan hasil analisis keintegrasian muatan pelajaran pada 4 komponen pembalajaran ditemukan 26 yang tidak terdapat keintegrasian, 201 keintegrasian secara intradisipliner dan ditemukan 39 keintegrasian secara multidisipliner. Jadi dapat disimpulkan bahwa kecenderungan keintegrasian muatan pelajaran pada 4 komponen pembelajaran di buku guru dan buku siswa Sekolah Dasar kelas I tema Lingkungan Bersih, Sehat dan Asri secara keseluruhan yaitu integrasi intradisipliner (201) keintegrasian.

Pertama, setelah dilakukan analisis terhadap komponen materi pembelajaran (MP) di buku guru dan buku siswa Sekolah Dasar kelas I tema Lingkungan Bersih, Sehat dan Asri. Hasilnya menunjukkan bahwa komponen materi pembelajaran (MP) memiliki tingkat keintegrasian sangat baik sebesar $94.8 \%$ dengan klasifikasi multidisipliner. Materi pembelajaran yang disajikan dalam buku guru dan buku siswa sebagian besar sudah sesuai dengan tujuan 
pembelajaran. Senada dengan pendapat Ernawati (2018); Fadlilah (2014) materi yang dimuat dalam buku teks hendaknya merupakan materi yang disusun saling berkaitan satu sama lain menjadi satu kesatuan dan tidak melenceng dari tujuan pengajaran. Misalnya, pada sub tema 1 pembelajaran 1 materi yang disajikan berjudul bekerjasama membersihkan rumah yang memfasilitasi integrasi muatan pelajaran Bahasa Indonesia dan PPkn. Hal ini sesuai dengan pendapat Mamat SB, dkk (dalam Prastowo, 2019:3) menyatakan bahwa pembelajaran tematik terpadu dapat dikelola melalui pengintegrasian materi dari beberapa mata pelajaran dalam satu topik pembicaraan yang disebut tema. Sejalan dengan pendapat Fajri (2018) siswa SD/MI masih belum mampu memahami konsep muatan pelajaran jika diberikan secara parsial atau terpisah. Sedangkan, kompetensi sikap spiritual dan sikap sosial terintegrasi dalam materi pembelajaran secara implisit. Sejalan dengan pendapat Ernawati (2018) menyatakan bahwa kompetensi inti tidak dituliskan secara eksplisit (gamblang) di dalam buku teks, namun ditulis secara implisit, sehingga guru diharapkan melakukan penguatan, pembiasaan, peneladanan, dan pembudayaan di sekolah. Sejalan pula dengan penelitian Oviana (2015) kempetensi dasar yang berkenaan dengan sikap spiritual dan sosial dikembangkan secara tidak langsung dalam pembelajaran pada saat peserta didik belajar kompetensi dasar pengetahuan (KI-3) dan kompetensi dasar ketrampilan (KI-4).3 Setiap guru yang mengimplementasikan kurikulum 2013 harus mampu menyajikan materi pada KD di $\mathrm{KI}-3$ dan proses pembelajaran pada KD di $\mathrm{KI}-4$ yang mengarah pada pencapaian $\mathrm{KD}$ dari $\mathrm{KI}-\mathrm{I}$ dan $\mathrm{KD}$ dari $\mathrm{KI}-2$ tanpa mengajarkan secara langsung. Adapun sikap spiritual yang terlihat berdasarkan temuan pada materi pembelajaran yaitu siswa lebih meningkatkan rasa syukur yang terlihat pada sub tema 4 pembelajaran 1 yang berjudul Bekerjasama Menjaga Lingkungan "Aku bersyukur bertetangga dengan siti". Sedangkan sikap sosial yang terlihat berdasarkan temuan pada materi pembelajaran yaitu siswa lebih meningkatkan rasa tanggungjawab "kami membersihkan saluran air bersama". Dengan demikian komponen materi pembelajaran pada buku guru dan buku siswa sudah baik dan dapat di implementasikan dalam pembelajaran di Sekolah Dasar.

Kedua, setelah dilakukan analisis terhadap komponen rancangan langkahlangkah kegiatan pembelajaran (RLLKP) di buku guru dan buku siswa Sekolah Dasar kelas I tema Lingkungan Bersih, Sehat dan Asri. Hasilnya menunjukkan bahwa komponen rancangan langkahlangkah kegiatan pembelajaran (RLLKP) memiliki tingkat keintegrasian baik sebesar 83,5\% dengan klasifikasi intradisipliner. Langkah-langkah kegiatan pembelajaran yang disajikan dalam buku guru dan buku siswa sudah mengintegrasikan kompetensi sikap, kompetensi keterampilan dan kompetensi pengetahuan dalam setiap proses pembelajaran. Hal ini menjadikan pembelajaran menjadi satu kesatuan yang utuh dari satu muatan pelajaran melalui aktivitas yang bervariasi yang memuat kegiatan ayo mengamati, ayo mencoba, ayo menulis, ayo membaca, ayo berlatih, ayo berdiskusi, ayo berkreasi, ayo menari, dan ayo bermain peran. Hal ini sesuai Standar Proses pada Kurikulum 2013 adalah penggunaan pendekatan saintifik, meliputi kegiatan mengamati, menanya, mengumpulkan informasi, menalar, dan mengomunikasikan dalam kegiatan pembelajaran. Sejalan dengan hasil penelitian (Sa'adah \& Mawardi, 2019) bahwa kebermaknaan meningkat dengan penerapan pembelajaran tematik terpadu menggunakan pendekatan saintifik. Adapun temuan yang terlihat pada langkah-langkah kegiatan pembelajaran pada sub tema 2 pembelajaran 4 yaitu (1) Ayo mengamati "Mintalah siswa mengamati gambar pada buku dan menceritakan apa yang mereka lihat pada gambar. Beri kesempatan kepada siswa yang masih perlu di motivasi rasa percaya 
dirinya" guru memberikan penekanan kepada siswa agar percaya diri yang merupakan contoh kegiatan yang mengandung kompetensi sikap (2) Ayo membaca "Beri kesempatan kepada siswa membaca teks percakapan pada buku siswa secara mandiri. Siswa akan berlatih membaca sendiri. Beri waktu 3-5 menit" guru memberikan penekanan kepada siswa agar membaca secara mandiri yang merupakan contoh kegiatan yang mengarah ke kompetensi pengetahuan, (3) Ayo menulis "siswa menuliskan kalimat ajakan dan tanggapan dari teks percakapan yang dibacanya" guru memberikan penekanan untuk menuliskan kalimat yang merupakan contoh kegiatan yang mengarah ke kompetensi keterampilan. Dengan demikian komponen rancangan langkah-langkah kegiatan pembelajaran pada buku guru dan buku siswa sudah baik dan dapat di implementasikan dalam pembelajaran di Sekolah Dasar.

Ketiga, setelah dilakukan analisis terhadap rancangan penilaian (RP) di buku guru dan buku siswa Sekolah Dasar kelas I tema Lingkungan Bersih, Sehat dan Asri. Hasilnya menunjukkan bahwa rancangan penilaian (RP) memiliki tingkat keintegrasian sangat baik sebesar 95,8\% dengan klasifikasi intradisipliner. Dalam rancangan penilaian pada buku guru dan buku siswa ditemukan instrumen yang digunakan untuk menilai kompetensi sikap, kompetensi pengetahuan dan kompetensi keterampilan. Penilaian kompetensi sikap dinilai melalui lembar observasi yang digunakan untuk pengamatan dan pencatatan sikap siswa selama kegiatan baik secara langsung maupun tidak langsung. Penilaian kompetensi pengetahuan dinilai melalui tes tulis, tes lisan dan penugasan. Sedangkan penilaian kompetensi keterampilan dinilai melalui kinerja yang dilengkapi dengan rubrik. Dari ketiga kompetensi tersebut sudah sesuai dengan penilaian pada kurikulum 2013 yaitu penilaian autentik. Sejalan dengan teori Prastowo (2019:67) menyatakan bahwa penilaian autentik adalah suatu jenis penilaian yang mengakomodasikan pengukuran pada seluruh aspek yang semestinya di ukur dalam proses pembelajaran baik pada aspek kompetensi sikap, kompetensi keterampilan maupun kompetensi pengetahuan. Sejalan pula dengan Kunandar (2013) bahwa penilaian hasil belajar siswa (dengan menggunakan penilaian autentik) mencangkup kompetensi sikap, pengetahuan dan keterampilan yang dilakukan secara berimbang sehingga dapat digunakan untuk menentukan posisi relatif setiap siswa terhadap standar yang telah ditetapkan. Dengan demikian komponen penilaian pada buku guru dan buku siswa sudah baik dan dapat diimplementasikan dalam pembelajaran di Sekolah Dasar.

Keempat, setelah dilakukan analisis terhadap rancangan media dan sumber belajar (RMSB) di buku guru dan buku siswa Sekolah Dasar kelas I tema Lingkungan Bersih, Sehat dan Asri. Hasilnya menunjukkan bahwa rancangan media dan sumber belajar (RMSB) memiliki tingkat keintegrasian sangat baik sebesar $89,7 \%$ dengan klasifikasi intradisipliner. Dalam media dan sumber belajar pada buku guru dan buku siswa ditemukan bahwa terdapat gambar, teks, alat musik ritmis, VCD, benda konkret dan lingkungan yang digunakan untuk memudahkan siswa dalam menguasai materi pembelajaran. Selain itu, dengan adanya media dan sumber belajar maka pembelajaran akan lebih menarik bagi siswa. Sejalan dengan teori Prastowo (2019:101) media dan sumber belajar merupakan suatu komponen sistem pembelajaran yang meliputi pesan, orang, bahan, alat teknik dan lingkungan yang dapat memengaruhi hasil belajar siswa. Sejalan pula dengan pendapat Crismono (2017) bahwa penggunaan lingkungan sebagai sumber belajar yang bersifat kontekstual dapat memperkaya wawasan siswa karena mereka belajar dan mengalami secara langsung. Dengan demikian komponen media dan sumber belajar pada buku guru dan buku siswa sudah baik dan dapat diimplementasikan dalam pembelajaran di Sekolah Dasar. 


\section{PENUTUP}

Berdasarkan hasil penelitian dan pembahasan di atas, maka peneliti menyimpulkan sebagai berikut:

1. Terdapat keintegrasian muatan pelajaran pada materi pembelajaran (MP) Sekolah Dasar kelas I tema Lingkungan Bersih, Sehat, dan Asri dengan tingkat keintegrasian sangat baik sebesar $94.8 \%$ dengan klasifikasi multidisipliner.

2. Terdapat keintegrasian muatan pelajaran pada rancangan langkahlangkah kegiatan pembelajaran (RLLKP) di buku guru dan buku siswa Sekolah Dasar kelas I tema Lingkungan Bersih, Sehat, dan Asri dengan tingkat keintegrasian baik sebesar 83,5\% dengan klasifikasi intradisipliner.

3. Terdapat keintegrasian muatan pelajaran pada rancangan penilaian (RP) di buku guru dan buku siswa Sekolah Dasar kelas I tema Lingkungan Bersih, Sehat, dan Asri dengan tingkat keintegrasian sangat baik sebesar 95,8\% dengan klasifikasi intradisipliner.

4. Terdapat keintegrasian muatan pelajaran pada rancangan media dan sumber belajar (RMSB) di buku guru dan buku siswa Sekolah Dasar kelas I tema Lingkungan Bersih, Sehat, dan Asri dengan tingkat keintegrasian sangat baik sebesar $89,7 \%$ dengan klasifikasi intradisipliner.

Berdasarkan simpulan diatas, maka ada beberapa saran yang dapat digunakan untuk meningkatkan kualitas pembelajaran dalam buku guru dan buku siswa yaitu pada komponen materi pembelajaran pada buku guru dan buku siswa sebaiknya dicantumkan sumber yang jelas, sedangkan pada tujuan pembelajaran yang terdapat pada buku guru, sebaiknya tujuan pembelajaran tidak disertai dengan dimensi sikap, karena dimensi sikap dilakukan secara implisit di dalam pembelajaran.

\section{DAFTAR RUJUKAN}

Agung, A. A. Gede. (2016). Statistika Dasar Untuk Pendidikan. Yogyakarta: Deepublish Publisher.
Crismono, P.C. (2017). Penggunaan Media Dan Sumber Belajar Dari Alam Sekitar Dalam Pembelajaran Matematika.Jurnal Gammath, Volume 2 Nomor 2, Agustus 2017

Ernawati, Y. (2018). Telaah Buku Teks Tematik Terpadu Kelas IV SD Kurikulum 2013.Jurnalilmiah Binaedukasi ISSN 1979-8598EISSN: 2655-8378.Tersedia pada: http://journal.binadarma.ac.id/index.p hp/jurnalbinaedukasi Vol. 11, No. 2, Desember 2018, 109-123.

Fadillah, M. 2014. Implementasi Kurikulum 2013. Yogyakarta: Ar-Ruzz Media

Fajri, Z. (2018). Bahan Ajar Tematik Dalam Pelaksanaan Kurikulum 2013.Jurnal Pedagogik, Vol. 05 No. 01, Januari-Juni 2018 ISSN: 23547960, E-ISSN : 2528-5793. Tersedia pada

https://ejournal.unuja.ac.id/index.php/ pedagogik.

Huber \& Hutchings. (2008). Integrative Learning: Mapping The Terrain International. Journal for The Scholarship of Teaching \& Learning. Vol.2 No.1.

Kunandar.(2013). Penilaian Autentik (Penilaian Hasil Belajar Peserta Didik berdasarkan Kurikulum 2013).Jakarta: Raja Grafindo Persada.

Novianto, A. \& Mustadi, A. (2015).Analisis Buku Teks Muatan Tematik Integratif, Scientific Approach, Dan Authentic Assessment Sekolah Dasar. Tesis.Program Pascasarjana Universitas Negeri Yogyakarta.

Oviana, W. (2015). Kemampuan Mahasiswa Mengintegrasikan Sikap Spiritual dan Sosial dalam Pembelajaran Berbasis Kurikulum 2013 (Kajian teoritis. Jurnal.arraniry.ac.id.

Prastowo, A. (2019). Analisis Pembelajaran Tematik Terpadu. Jakarta: Prenadamedia Group. 
Randle, I. (2010). "The Measure of Success: Integrated Thematic Instruction". The Clearing House, 71, 85-87.

Rumahlatu, dkk. (2016). An Analysis of the Readiness and Implementation of 2013 Curriculum in The West Part of Seram District, Maluku Province, Indonesia. International Journal Of Environmental \& Science Education 2016, Vol. 11, No. 12, 5662-5675.

Sa'adah, M. \& Mawardi.(2019). Peningkatan Kebermaknaan Dan Hasil Belajar Siswa Melalui Desain Pembelajaran Tematik Terpadu Alternatif Berbasis Projek Pada Siswa Kelas 5.Jurnal Riset Teknologi dan Inovasi Pendidikan p-ISSN: 2622-4763 | e-ISSN: 2622-2159 | Vol. 2 No. 1 (Januari) 2019, Hal. 1-14

Sugiyono, (2013).Metode Penelitian Pendidikan Pendekatan Kuantitatif, Kualitatif, Dan R\&D. Bandung: Alfabeta.

Suryati, D. A. (2010). Efektivitas Pelaksanaan Pembelajaran Tematik di Kelas Awal SD di Kabupaten Gianyar dan Badung. Tesis. Program Pascasarjana Universitas Pendidikan Ganesha. 